\title{
A High Frequency of Bacillus subtilis Glutamine Auxotrophs Revert to Cold Sensitivity
}

\author{
By DAVID H. LAMB, $†$ DENNIS R. DEAN $\ddagger$ AND \\ ARTHUR I. ARONSON* \\ Department of Biological Sciences, Purdue University, West Lafayette, Indiana 47907 , \\ U.S.A.
}

(Received 17 A ugust 1981; revised 23 September 1981)

\begin{abstract}
A large number of spontaneous conditional revertants of Bacillus subtilis glutamine auxotrophs were isolated by plating cells on minimal medium and incubating them at various temperatures. No heat-sensitive revertants were found among 2000 scored; however, revertants with a cold-sensitive glutamine requirement were quite common. Growth of the latter class ceased immediately upon transfer to the restrictive temperature implying that glutamine synthetase activity was affected. Mapping data are consistent with a genetic location in or near $g \ln A$, the structural gene for glutamine synthetase, for all cold-sensitive revertants tested. These revertants are likely to have second site suppressor mutations in $g \ln A$ since many have altered levels or kinetics of glutamine synthetase activity or a changed pattern of feedback inhibition.
\end{abstract}

\section{INTRODUCTION}

The regulation of enzymes involved in assimilation of ammonia and other nitrogen sources in certain Gram-negative bacteria has been extensively studied (for review, see Tyler, 1978). By contrast, the control of nitrogen metabolism in bacilli is as yet poorly understood. There appear to be significant differences, however, in nitrogen metabolism between Gram-negative organisms, such as Escherichia coli, and bacilli. Most Bacillus species lack detectable glutamate dehydrogenase (EC 1.4.1.4) (Hong et al., 1959). Consequently, the concerted activity of glutamate synthase (EC 1.4.1.13) and glutamine synthetase (GS; EC 6.3.1.2) are pivotal for nitrogen metabolism whether the ammonia concentration of the medium is high or low. Kane \& Deshpande (1979) have reported that Bacillus subtilis contains detectable glutamate dehydrogenase active only during the late-exponential phase of growth. Secondly, some Bacillus species, including $B$. subtilis, lack a glutaminyl-tRNA synthetase (Wilcox \& Nirenberg, 1968). Glutaminyl-tRNA ${ }^{\text {Gln }}$ is formed by first esterifying glutamate to tRNA ${ }^{\text {Gln }}$ then amidating the glutamate to form glutaminyl-tRNA ${ }^{\text {Gln }}$. The glutamine formed by GS is used therefore mainly or entirely as an amido donor in biosynthetic reactions. Finally, there is no direct evidence for in vivo adenylylation of GS in B. subtilis (Deuel et al., 1970; Gancedo \& Holzer, 1968) as has been described by Ginsburg \& Stadtman (1973) and Gancedo \& Holzer (1968) for Gram-negative organisms.

In addition to the differences noted above, there is the possibility that GS may be involved in the regulation of sporulation (Elmerich \& Aubert, 1972; Reysset \& Aubert, 1975). Overall, there appear to be a number of unique aspects to the regulation of nitrogen metabolism in bacilli. All of the glutamine auxotrophs previously isolated contained some GS activity,

† Present address: Public Health Research Institute of the City of New York, 455 First Avenue, New York, N.Y. 10016, U.S.A.

$\ddagger$ Present address: Institute for Enzyme Research, University of Wisconsin, Madison, Wisconsin 53706, U.S.A. 
especially when $\mathrm{Mn}^{2+}$ was employed as the activating cation in assays (Dean et al., 1977; Dean \& Aronson, 1980). The inability to isolate mutants devoid of activity implied that the enzyme had an indispensable function, at least for the range of selective conditions used. Conditional revertants were isolated, therefore, in order to study possible pleiotropic regulatory properties of this enzyme. While no high temperature-sensitive revertants were found, there was a high frequency of cold-sensitive revertants. The physiology of these mutants has been studied in order to understand the basis for the cold-sensitivity.

\section{METHODS}

Bacterial strains and cultivation. The strains of Bacillus subtilis used in this study are listed in Table 1. Glutamine auxotrophs were isolated from $\mathrm{JH} 641$ or $\mathrm{JH} 642$ by mutagenesis with $N$-methyl- $N^{\prime}$-nitro- $N$ nitrosoguanidine (NTG) (Adelberg et al., 1965) or ethyl methanesulphonate (EMS) (Ito \& Spizizen, 1971). Following mutagenesis, glutamine auxotrophs were enriched by penicillin treatment (Dean et al., 1977) of cultures resuspended in a minimal salts medium (Schaeffer et al., 1965), or in minimal medium supplemented with all amino acids (each at $50 \mathrm{\mu g} \mathrm{ml}^{-1}$ ) except glutamine or with $0.1 \%(\mathrm{w} / \mathrm{v})$ nutrient broth. Appropriate transformations were then performed to introduce the mutant alleles into isogenic backgrounds (Dean et al., 1977). Spontaneous revertants of mutant DRD2 were obtained by spreading cells on minimal agar lacking glutamine followed by incubation at $30^{\circ} \mathrm{C}$. Colonies to be tested were streaked twice to give single colonies under selective conditions to assure purity.

Conditional revertants were spontaneously occurring variants and were isolated as follows. A single colony of the appropriate glutamine auxotroph growing on tryptose blood agar (Difco) plus $1 \mathrm{mg}$ glutamine $\mathrm{ml}^{-1}$ was used to inoculate a flask containing Penassay broth (Difco) plus glutamine and grown to the late-exponential phase at $37^{\circ} \mathrm{C}$. Cells were collected by centrifugation, resuspended in an equal volume of minimal medium (Spizizen, 1958), and about $10^{8}$ were plated on minimal medium lacking glutamine. The plates were incubated at either $45^{\circ} \mathrm{C}$ or $30^{\circ} \mathrm{C}$ for $2-7 \mathrm{~d}$. All revertants studied sporulated well and were stored as spores in sterile silica gel.

Preparation of crude extracts. Crude extracts were prepared from cells $(50 \mathrm{ml})$ grown in minimal medium plus 2 $\mathrm{mg}$ glutamine $\mathrm{ml}^{-1}$ to the late-exponential phase at $45^{\circ} \mathrm{C}$. Cells were harvested by centrifugation and washed twice with $50 \mathrm{~mm}$-imidazole $/ \mathrm{HCl}(\mathrm{pH} 7.0$ ). The cell pellet was resuspended in 2-3 $\mathrm{ml}$ of the same buffer containing $100 \mu \mathrm{g}$ lysozyme $\mathrm{ml}^{-1}$ and incubated at $37^{\circ} \mathrm{C}$ for $30-60 \mathrm{~min}$. To ensure complete lysis and reduced viscosity, extracts were placed on ice and sonicated for 30-60 s in a Branson sonicator fitted with a microtip using $1 \mathrm{~s}$ pulses.

Enzyme assay. Glutamine synthetase (GS) was assayed by the glutamyl transferase method as described previously (Dean et al., 1977). The reaction mixture contained $50 \mathrm{mM}$-imidazole/ $\mathrm{HCl}(\mathrm{pH} 7.0), 10 \mathrm{mM}-\mathrm{ATP}, 100$ mM-glutamate, $40 \mathrm{~mm}$-hydroxylamine and either $40 \mathrm{~mm}-\mathrm{MgSO}_{4}$ or $10 \mathrm{~mm}-\mathrm{MnCl}_{2}$. The reaction, in a final volume of $2 \mathrm{ml}$, was initiated by the addition of crude extract and terminated by the addition of ferric chloride reagent (Elliot, 1955). For spot assays of individual colonies, a single colony was scraped off with a toothpick and resuspended in $150 \mu \mathrm{l}$ of the above reaction buffer $\left(\mathrm{Mn}^{2+}\right.$-stimulated) supplemented with lysozyme and cetyltrimethylammonium bromide, each at $100 \mu \mathrm{g} \mathrm{ml}^{-1}$. After incubation at $37^{\circ} \mathrm{C}$ for $30 \mathrm{~min}$, the reaction was terminated by the addition of ferric chloride reagent and the amount of colour formed was estimated visually. Results of GS assays are expressed as nmol $\gamma$-glutamyl hydroxamate formed $\mathrm{min}^{-1}$ (mg protein) ${ }^{-1}$. All values are the average of at least two determinations. Protein was assayed by the Lowry method.

Transformation. Transformation was done as described by Anagnostopoulos \& Spizizen (1961) or Bott \& Wilson (1968). Transformations were performed by treating competent $B$. subtilis cultures with 0.1 to $0.001 \mu \mathrm{g}$ DNA $\mathrm{ml}^{-1}$ purified from donor cells according to the procedure of Marmur (1961).

\section{Table 1. Bacterial strains}

\section{Strain Genotype}

JH641

JH642

$168 \mathrm{I}^{-} \mathrm{Thy}^{-}$

DRD2

DRD101

DRD4

DRD7

DRD17

DRD4 1

DL10

DL12, 13, 14, 15

DL4, 5, 11

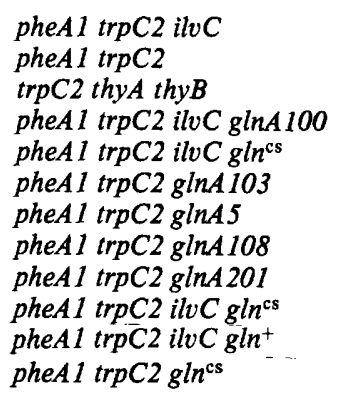

pheA1 trpC2 ilvC

trpC2 thyA thy $B$

pheA1 trpC2 ilvC glnA100

pheAl trp 2 iluC gln

pheA1 trpC2 glnA5

pheA1 trpC2 $\operatorname{gln} A 108$

pheA1 trpC2 glnA 201

pheA1 trpC2 ilvC gln

pheA1 trpC2 gln $^{\mathrm{cs}}$
Source

\author{
J. Hoch \\ J. Hoch \\ J. Hoch \\ Dean et al. (1977) \\ EMS mutagenesis of DRD2 (Dean, 1979) \\ Dean et al. (1977) \\ EMS mutagenesis of JH642 (Dean, 1979) \\ NTG mutagenesis of JH642 (Dean, 1979) \\ EMS mutagenesis of JH642 (Dean, 1979) \\ From DRD2 (this study) \\ From DRD2 (this study) \\ From DRD4 (this study)
}


Table 2. Relative numbers of revertants of glutamine auxotrophs when selected at different temperatures

\begin{tabular}{|c|c|c|c|}
\hline \multirow{2}{*}{ Parent } & \multicolumn{2}{|c|}{ No. of revertants } & \multirow{2}{*}{$\begin{array}{c}\text { Percentage of } \\
45^{\circ} \mathrm{C} \text { revertants } \\
\text { with } \mathrm{Gln}^{\mathrm{cs}} \text { phenotype }\end{array}$} \\
\hline & At $30^{\circ} \mathrm{C}$ & At $45^{\circ} \mathrm{C}$ & \\
\hline $\begin{array}{l}\text { DRD2 } \\
\text { DRD4 } \\
\text { DRD7 } \\
\text { DRD17 } \\
\text { DRD41 }\end{array}$ & $\begin{array}{r}22 \\
0 \\
220 \\
76 \\
\text { ca } 700\end{array}$ & $\begin{array}{r}47 \\
55 \\
280 \\
120 \\
\text { ca } 500\end{array}$ & $\begin{array}{l}50 \\
58 \\
\text { NT } \\
17 \\
\text { NT }\end{array}$ \\
\hline & & ot tested. & \\
\hline
\end{tabular}

\section{RESULTS}

\section{Isolation of revertants}

Spontaneously occurring glutamine-independent revertants were isolated from five glutamine auxotrophs altered in $g \ln A$. Of approximately 2000 revertants isolated from three of these strains (DRD2, DRD17 and DRD41) in 12 independent selections at $30^{\circ} \mathrm{C}$, none were found to have a temperature-sensitive glutamine requirement when scored at $45^{\circ} \mathrm{C}$. In contrast, all three strains from which revertants were isolated at $45^{\circ} \mathrm{C}$ yielded cold-sensitive glutamine auxotrophs at a high frequency.

The apparent reversion frequency was dependent on the temperature at which the revertants were selected (Table 2). In most, but not all cases, selection at the higher temperature resulted in a higher apparent reversion frequency. Although the number of revertants isolated from a particular auxotroph at a particular temperature varied among experiments, the ratio of the reversion frequencies at $30^{\circ} \mathrm{C}$ to $45^{\circ} \mathrm{C}$ for a particular auxotroph was generally reproducible. Three independent selections for spontaneous revertants of DRD4 at $45^{\circ} \mathrm{C}$ yielded an average reversion frequency of $7 \times 10^{-7}$.

The mutation conferring glutamine auxotrophy in strain DRD2 $(g \ln A 100)$ also resulted in a 6- to 15-fold overproduction of GS protein (Dean et al., 1977). The $\mathrm{Mn}^{2+}$-stimulated GS activity of several revertants isolated at $45^{\circ} \mathrm{C}$ was determined by spot assays of single colonies (see Methods) and a majority $(10 / 16)$ retained the high activity of the parental strain. When selection was performed at $30^{\circ} \mathrm{C}$, however, nearly all of the revertants examined (30/32) had $\mathrm{Mn}^{2+}$-stimulated GS levels similar to the wild-type strain, JH641 (Table 4). In both experiments, several colonies were used to start cultures in liquid medium and the GS activity estimated by the spot assay was verified by the more quantitative assay. Both experiments were performed with revertants pooled from four independent selections to preclude the possibility that random fluctuations in the frequency of different revertant types might bias the results.

\section{Growth studies}

On shifting cultures growing in minimal medium with ammonium sulphate as the sole nitrogen source from $45^{\circ} \mathrm{C}$ to $30^{\circ} \mathrm{C}$, cultures of the wild-type strain JH641 continued to grow, but cultures of the cold-sensitive revertant DRD101 ceased growth immediately (Fig. 1). Addition of glutamine or glutamate permitted growth of DRD101 at the lower temperature (data not shown). The immediate effect on growth after shifting cold-sensitive revertants (others behaved in the same way as DRD101) to $30^{\circ} \mathrm{C}$ is consistent with a defect in GS activity rather than in GS synthesis. If the latter were the only alteration in these mutants, then 


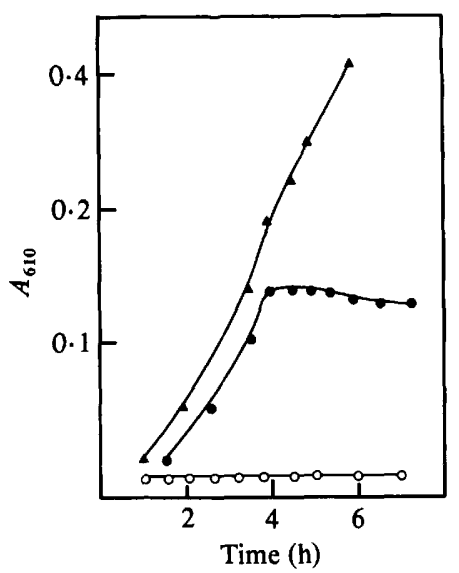

Fig. 1. Effect of a temperature shift on the growth of strains in minimal medium with $\left(\mathrm{NH}_{4}\right)_{2} \mathrm{SO}_{4}$ as the nitrogen source. Cultures growing at $45^{\circ} \mathrm{C}$ were shifted to $30^{\circ} \mathrm{C}$ at $4 \mathrm{~h}$. Absorbance at $610 \mathrm{~nm}$ was measured in a Beckman DB-G spectrophotometer. Strains: A, JH641; O, DRD101; O, DRD2.

\section{Table 3. Genetic mapping of $g \ln A$ revertants}

Transformation crosses were performed as described in Methods.

\begin{tabular}{|c|c|c|c|c|c|}
\hline \multirow[b]{2}{*}{ Donor } & \multirow[b]{2}{*}{ Recipient } & \multicolumn{3}{|c|}{$\begin{array}{l}\text { Phenotype of Thy } \\
\text { transformants }\end{array}$} & \multirow{2}{*}{$\begin{array}{l}\text { Percentage } \\
\text { cotransfer }\end{array}$} \\
\hline & & $\mathrm{Gln}^{+}$ & $\mathrm{Gln}^{-}$ & $G \ln ^{\mathrm{cs}}$ & \\
\hline DRD2 $(g \ln A 100)$ & $168 \mathrm{I}^{-} \mathrm{Thy}^{-}$ & 116 & 9 & - & 7.2 \\
\hline DRD101 $\left(g \ln { }^{\mathrm{cs}}\right)$ & $168 \mathrm{I}^{-} \mathrm{Thy}^{-}$ & 423 & 0 & 50 & $10 \cdot 6$ \\
\hline DL5 $\left(g \ln ^{\mathrm{cs}}\right)$ & $168 \mathrm{I}^{-\mathrm{Thy}^{-}}$ & 63 & 0 & 9 & $12 \cdot 5$ \\
\hline DL10 $\left(g \ln ^{\mathrm{cs}}\right)$ & $168 \mathrm{I}^{-} \mathrm{Thy}^{-}$ & 264 & 2 & 16 & 6.4 \\
\hline DL12 $\left(g \ln ^{+}\right)$ & $168 \mathrm{I}^{-} \mathrm{Thy}^{-}$ & 242 & 0 & - & 0 \\
\hline
\end{tabular}

* Percentage of Thy ${ }^{+}$transformants that acquired the Gln ${ }^{-}$or $\mathrm{Gln}^{\mathrm{cs}}$ phenotype.

pre-existing enzyme should have been able to sustain growth for some period after the shift-down.

\section{Genetic mapping of revertants}

Two types of transformation crosses were performed to determine the genetic location(s) of the lesions conferring the $G \ln ^{\mathrm{cs}}$ phenotype. Genetic linkage to thy $A$ was tested by preparing DNA from several revertant strains and using this DNA to transform strain $168 \mathrm{I}^{-}$Thy $^{-}$to $\mathrm{Thy}^{+}$. Thy ${ }^{+}$transformants were selected at $45^{\circ} \mathrm{C}$, to suppress $t$ hy $B^{+}$transformants (Neuhard et al., 1978), in the presence of glutamine and scored for the $\mathrm{Gln}^{-}$phenotype at both $30^{\circ} \mathrm{C}$ and $45^{\circ} \mathrm{C}$. If the lesion responsible for the $\mathrm{Gln}^{\mathrm{cs}}$ phenotype were closely linked to the parental $g \ln A$ marker, $g \ln ^{\mathrm{cs}}$ should show the same linkage to $\operatorname{thy} A$ as does $g \ln A$. If the $g \ln ^{\mathrm{cs}}$ lesion were unlinked to the $g \ln A-t h y A$ region, however, none of the thy $A^{+}$transformants would be expected to be $g \ln ^{\mathrm{cs}}$ (or $g \ln ^{+}$in the case of prototrophic revertants). This cross was performed for three cold-sensitive revertants and one prototrophic revertant (Table 3). The results were consistent with a location for $g \ln$ cs at or near $g \ln A$, since the percentage cotransfer values were similar to those previously found for $g \ln A$ and $\operatorname{thy} A$ (Dean et al., 1977).

Since the markers tested mapped in the $g \ln A$ region, we used another genetic test to map the lesion more precisely. DNA was prepared from strain JH641 $\left(g \ln A^{+}\right)$and used to transform strain DL11 $\left(g l^{\mathrm{cs}}\right)$ to glutamine prototrophy at $30^{\circ} \mathrm{C}$. The resulting glutamine 
Table 4. Growth rate and GS activity of revertants

\begin{tabular}{|c|c|c|c|c|c|c|c|}
\hline \multirow[b]{2}{*}{ Strain } & \multirow[b]{2}{*}{ Temp.* } & \multicolumn{2}{|c|}{$\begin{array}{c}\begin{array}{c}\text { Specific GS } \\
\text { activity }\end{array} \\
\end{array}$} & \multicolumn{3}{|c|}{$\begin{array}{c}\begin{array}{c}\text { Percentage activity remaining in } \\
\text { presence of } 5 \mathrm{~mm} \text { inhibitor }\end{array} \\
\text {. }\end{array}$} & \multirow{2}{*}{$\begin{array}{c}\text { Mean } \\
\text { doubling } \\
\text { time } \\
\text { (min) }\end{array}$} \\
\hline & & $\begin{array}{l}\text { With } \\
\mathrm{Mg}^{2+}\end{array}$ & $\begin{array}{l}\text { With } \\
\mathrm{Mn}^{2+}\end{array}$ & Alanine & Glycine & Glutamine & \\
\hline JH641 & - & $10 \cdot 5$ & 7.6 & 54 & 79 & $26 \cdot 7$ & 46 \\
\hline DRD2 $(g \ln A 100)$ & - & 3.9 & $45 \cdot 7$ & 100 & 99 & 89 & - \\
\hline DRD101 $\left(g \ln ^{\mathrm{cs}}\right)$ & $37^{\circ} \mathrm{C}$ & $18 \cdot 3$ & 32.8 & 96 & 97 & 94 & 75 \\
\hline DL $10\left(g \ln ^{\mathrm{cs}}\right)$ & $45^{\circ} \mathrm{C}$ & $28 \cdot 2$ & $36 \cdot 1$ & 100 & 99 & 83 & 60 \\
\hline DL12 $\left(g \ln ^{+}\right)$ & $30^{\circ} \mathrm{C}$ & $6 \cdot 5$ & $4 \cdot 2$ & NT & NT & NT & NT \\
\hline $\operatorname{DL} 13\left(g \ln ^{+}\right)$ & $30^{\circ} \mathrm{C}$ & $7 \cdot 1$ & $4 \cdot 8$ & NT & NT & NT & NT \\
\hline DL14 $\left(g \ln ^{+}\right)$ & $30^{\circ} \mathrm{C}$ & $5 \cdot 0$ & $3 \cdot 3$ & NT & NT & NT & NT \\
\hline DL15 $\left(g \ln ^{+}\right)$ & $30^{\circ} \mathrm{C}$ & $2 \cdot 1$ & $22 \cdot 3$ & NT & NT & NT & NT \\
\hline DRD4 $(g \ln A 103)$ & - & $5 \cdot 1$ & $12 \cdot 7$ & 94 & 100 & 100 & - \\
\hline DL4 $\left(g \ln ^{\mathrm{cs}}\right)$ & $45^{\circ} \mathrm{C}$ & 5.4 & 22.7 & 54 & 80 & NT & 64 \\
\hline DL5 $\left(g \ln ^{\mathrm{cs}}\right)$ & $45^{\circ} \mathrm{C}$ & $3 \cdot 3$ & 12.9 & 68 & 86 & NT & ca 150 \\
\hline DL11 $\left(g \ln ^{\mathrm{cs}}\right)$ & $45^{\circ} \mathrm{C}$ & 3.9 & $43 \cdot 7$ & 75 & 100 & 100 & 80 \\
\hline
\end{tabular}

prototrophs would be expected to carry the wild-type $g \ln A^{+}$allele. Thirteen transformants were purified by two isolation streakings under selective conditions. DNA was prepared from each of these strains and used to transform strain DRD4 (the parent of DL11) to glutamine prototrophy at $45^{\circ} \mathrm{C}$. If the $g \ln ^{\mathrm{cs}}$ gene were unlinked to the $g \ln A^{+}$locus, then the DNA from the donors should transform DRD4 to either $g l n^{+}$or $g l n^{\text {cs }}$ at approximately equal frequencies. Nearly all transformants ( 940 of 942 ) from the above crosses were $g l n^{+}$indicating very close linkage between the $g \ln A 103$ mutation in strain DRD4 and the $g \ln ^{\text {es }}$ lesion in DL11. As a control, strain DRD4 was transformed with DNA from DL11 $\left(g \ln ^{\mathrm{cs}}\right)$ and all transformants were $g \ln ^{\mathrm{cs}}$.

\section{Biochemical studies}

The genetic results were consistent with the hypothesis that the cold-sensitive revertants were second site mutations in the GS structural gene. It is difficult to establish this close linkage unambiguously due to the paucity of suitable genetic markers in the glnA region of the chromosome and the lack of a routine procedure for complementation analysis in $B$. subtilis. For these reasons we characterized the GS activity of several revertants biochemically (Table 4). The $\mathrm{Mg}^{2+}$-stimulated activities in revertants were generally lower than those observed for the wild-type strain JH641. All cold-sensitive revertants examined had $\mathrm{Mn}^{2+}$-stimulated activities as high, or higher, than the $g \ln$ parent strain and higher than that observed for strain JH641, consistent with the results obtained using the spot assay described above. In contrast, prototrophic revertants isolated at $30^{\circ} \mathrm{C}$ had $\mathrm{Mn}^{2+}$-stimulated activities that were similar to that of strain JH641 or were intermediate between the activities observed for JH641 and the auxotrophic parent.

There was no obvious correlation between the amount of GS activity observed in crude extracts and the growth rate measured at $45^{\circ} \mathrm{C}$ in the absence of glutamine (Table 4). It is possible that the lack of correlation is due to alterations in the affinity of GS for one or more of its substrates (Dean et al., 1977). This altered affinity may not be apparent in assays of crude extracts performed with saturating substrate concentrations. At least one revertant contained GS with altered kinetic properties (see below).

Feedback inhibition of GS activity in crude extracts from several revertants by alanine, glycine or glutamine was also measured (Table 4). In contrast to the auxotrophic parent 
strain, GS activity of revertants of DRD4 was inhibited by alanine and/or glycine. Results for strain DL11 suggest that the physical sites on the GS protein responsible for feedback inhibition by alanine and glycine may be separate since the GS activity of this strain was partially inhibited by alanine but not by glycine.

Growth of strains DL5 and DL11, but not of any other strains tested, was strongly inhibited by addition of $10 \mathrm{~mm}$-alanine to minimal medium. This inhibition was reversed by simultaneous addition of glutamine (data not shown). These two strains may possess relatively low levels of GS activity in vivo (as judged by their growth rates in the absence of glutamine) but near normal levels of feedback inhibition of alanine, and thus be more susceptible to metabolite imbalance. This interpretation is consistent with earlier kinetic studies (Deuel \& Stadtman, 1970; Deuel \& Prusiner, 1974) that show that B. subtilis GS is regulated by feedback inhibition rather than by an adenylylation-deadenylylation system. The amount of feedback inhibition by alanine, glycine or glutamine was the same irrespective of whether the assay was performed at $25^{\circ} \mathrm{C}$ or $45^{\circ} \mathrm{C}$ for any strain tested.

\section{DISCUSSION}

Several hundred glutamine auxotrophs have been isolated after treatment of $B$. subtilis with a variety of mutagens (or spontaneously) and using several enrichment techniques (Dean, 1979). The inability to find mutants totally devoid of GS activity implied that there was selective pressure to sustain some level of GS antigen, perhaps related to pleiotropic regulatory functions of this enzyme. All of the mutations were mapped close to thy $A$ and very close to each other on the basis of recombination indices. Since some of the mutants studied have GS activities with altered properties (electrophoretic, kinetic or temperature stability), it is likely that many have alterations in the structural gene although some could be altered in a closely linked regulatory gene.

All of the revertants conferring cold sensitivity mapped in the $\operatorname{thy} A-g \ln A$ region of the $B$. subtilis chromosome, and for at least one revertant the mutation was very closely linked to $g \ln A$, consistent with the view that most, if not all, of the revertants examined may have secondary alterations in $g \ln A$ that suppress the original auxotrophic mutation. This conclusion is supported by the observation that GS from many of the revertants, in contrast to the $g$ ln parent, was inhibited by alanine and/or glycine (Table 4). A revertant that did not regain the ability to be feedback-inhibited (DL10) had altered kinetic properties of its GS in response to an increasing concentration of sodium glutamate. The $V_{\max }$ appeared to be altered when assays were done at either $25^{\circ} \mathrm{C}$ or $45^{\circ} \mathrm{C}$. Other revertants were not tested for altered kinetic properties.

The possibility that the mutations conferring a $\mathrm{Gln}^{+}$or $\mathrm{Gln}{ }^{\mathrm{cs}}$ phenotype lie in a $g \ln A$-linked regulatory gene whose product affects GS activity, rather than in $g \ln A$ itself, has not been disproved. However, there is no evidence for a GS cascade regulatory system in $B$. subtilis (Gancedo \& Holzer, 1968; Deuel \& Stadtman, 1970; Deuel \& Prusiner, 1974) as there is in enteric bacteria, and it has been proposed that $B$. subtilis GS activity is regulated directly by feedback inhibition. Our previous results are consistent with this idea in that all 50 glutamine auxotrophs mapped showed similar linkage to thy $A$ and were very closely linked to each other, but the data are not adequate to rule out a closely linked regulatory locus.

Cold-sensitivity in micro-organisms has been shown to be due to mutations in a wide variety of genes and to result from several different mechanisms. Perhaps the most familiar examples are alterations in components of the translational apparatus. Many alterations affecting ribosomal components confer a cold-sensitive phenotype (Jaskunas et al., 1974). Cold-sensitive mutations affecting a tRNA-modifying enzyme (Brenchley \& Ingraham, 1973) and RNA polymerase (Gragarov et al., 1980) have also been described. It is possible, therefore, that the phenotypes of the revertants were due to indirect suppression of glutamine auxotrophy by secondary mutations in components of the translational or transcriptional 
apparatus. This is highly unlikely since no genes involved in transcription or translation have been mapped in the $g \ln A$ region of the $B$. subtilis chromosome (Henner \& Hoch, 1980) and the revertants examined in this study were altered in GS activity, not synthesis, and displayed alterations in the GS protein as noted above.

Cold-sensitive metabolic defects have been noted by others. In some cases, cold-sensitivity is due to hypersensitivity to feedback inhibition at the restrictive temperature (O'Donovan \& Ingraham, 1965; Abd-El-Al \& Ingraham, 1969). In all $g \ln ^{\mathrm{cs}}$ revertants examined, the level of feedback inhibition observed did not vary as a function of temperature. This observation is not conclusive since GS activity in these revertants may be hypersensitive to inhibition by metabolites that normally have little physiological effect, or to a particular combination of metabolites at the restrictive temperature. Nevertheless, it seems likely that the $g \ln ^{\mathrm{cs}}$ phenotype is due to differential levels of enzyme activity per se at the permissive and restrictive temperatures, a conclusion supported by the observation that in at least one cold-sensitive revertant (DL11) the ratio of the GS activities measured at $25^{\circ} \mathrm{C}$ and $45^{\circ} \mathrm{C}$ is approximately twofold greater than that observed for the wild-type strain JH641 (data not shown). Cold-sensitivity due to inhibition of enzyme activity has been demonstrated in at least two other cases (Hoffman \& Ingraham, 1970; Kohno \& Roth, 1979).

The reason for the prevalence of cold-sensitive revertants was suggested by the 10 - to 20 -fold greater activity of GS when assayed at $45^{\circ} \mathrm{C}$ versus $25^{\circ} \mathrm{C}$. The difference was reflected physiologically by the observation that the glutamine requirement of strain DRD2 is slightly leaky at $45^{\circ} \mathrm{C}$ but not at $30^{\circ} \mathrm{C}$. It is possible that $B$. subtilis $\mathrm{GS}$ activity and/or stability is greater at higher temperatures at least in some of the $g \ln A$ mutants. This stability could explain the higher apparent reversion frequency at $45^{\circ} \mathrm{C}$ since at higher temperatures partial revertants would regain enough enzyme activity to allow growth, whereas at $30^{\circ} \mathrm{C}$ the selection for a return to the wild-type or near wild-type protein conformation would be more stringent. The most likely explanation, although not the only possible one, is that most or all of the revertants studied represent second site mutations in $g \ln A$ that suppress or partially suppress the original mutation.

Finally, it may be noted that the isolation of spontaneous revertants at $30^{\circ} \mathrm{C}$ that regain both prototrophy and wild-type levels of GS activity (Table 4) supports our earlier conclusion (Dean et al., 1977, Dean \& Aronson, 1980) that the glutamine requirement and overproduction of GS protein in strain DRD2 (as well as some other glutamine auxotrophs) is due to a single mutation. The regulation of production of GS would thus involve the structural gene and possibly a closely linked regulatory region.

Research supported by a Public Health Service grant GM20606 from the National Institute of General Medical Sciences. D.R.D. was a trainee on a Public Health Service regulatory biology training grant. Dr J. Brenchley provided excellent critical advice.

\section{REFERENCES}

AbD-El-Al, A. \& IngRaham, J. L. (1969). Cold sensitivity and other phenotypes resulting from mutation in pyrA gene. Journal of Biological Chemistry 244, 4039-4045.

Adelberg, E. A., Mandel, M. \& Chen, G. C. C. (1965). Optimal conditions for mutagenesis by $N$ methyl- $N^{\prime}$-nitro- $N$-nitrosoguanidine in Escherichia coli K12. Biochemical and Biophysical Research Communications 18, 788-795.

Anagnostopoulos, C. \& Spizizen, J. (1961). Requirements for transformation in Bacillus subtilis. Journal of Bacteriology 81, 741-746.

BotT, K. F. \& Wilson, G. A. (1968). Metabolic and nutritional factors influencing the development of competence for transfection of Bacillus subtilis. Bacteriological Reviews 32, 370-378.

BrENCHLEY, J. E. \& INGRAHAM, J. L. (1973). Characterization of a cold-sensitive his $W$ mutant of Salmonella typhimurium. Journal of Bacteriology 114, 528-536.

DEAN, D. R. (1979). Ph.D. thesis, Purdue University, U.S.A.

DeAN, D. R. \& ARonson, A. I. (1980). Selection of Bacillus subtilis mutants impaired in ammonia assimilation. Journal of Bacteriology 141, 985988. 
Dean, D. R., Hoch, J. A. \& Aronson, A. I. (1977). Alteration of the Bacillus subtilis glutamine synthetase results in overproduction of the enzyme. Journal of Bacteriology 131, 981-987.

Deuel, T. F. \& Prusiner, S. (1974). Regulation of glutamine synthetase from Bacillus subtilis by divalent cations, feedback inhibitors, and Lglutamine. Journal of Biological Chemistry 249, 257-264.

Deuel, T. F. \& Stadtman, E. R. (1970). Some kinetic properties of Bacillus subtilis glutamine synthetase. Journal of Biological Chemistry 245, 5206-5213.

Deuel, T. F., Ginsburg, A., Yeh, J., Shelton, E. \& Stadtman, E. R. (1970). Bacillus subtilis glutamine synthetase purification and physical characterization. Journal of Biological Chemistry 245, 5195-5205.

Elliot, W. H. (1955). Glutamine synthetase. Methods in Enzymology 2, 337-342.

Elmerich, C. \& Aubert, J. P. (1972). Role of glutamine synthetase in the repression of bacterial sporulation. Biochemical and Biophysical Research Communications 46, 892-897.

GANCEDO, C. \& Holzer, H. (1968). Enzymatic inactivation of glutamine synthetase in Enterobacteriaceae. European Journal of Biochemistry 4, 190-192.

GinsburG, A. \& Stadtman, E. R. (1973). Regulation of glutamine synthetase in Escherichia coli. In The Enzymes of Glutamine Metabolism, pp. 9-44. Edited by S. Prusiner \& E. R. Stadtman. New York: Academic Press.

Gragarov, A. I., Kocherginskaya, S. A., LoRIONOV, O. A., KAYAEVA, E. S. \& Nikiforov, V. G. (1980). Cold-sensitive mutations in $\beta$ and $\beta^{\prime}$ subunit genes affecting the interaction of RNA polymerase with promoters. Molecular and General Genetics 180, 399-403.

HenNer, D. S. \& Hoch, J. A. (1980). The Bacillus subtilis chromosome. Microbiological Reviews 44, 57-82.

HoffMAN, B. \& INGRAham, J. (1970). A cold-sensitive mutant of Salmonella typhimurium which requires tryptophan for growth at $20^{\circ} \mathrm{C}$. Biochimica et biophysica acta 201, 300-308.

Hong, M. M., Shen, S. C. \& Braunstein, A. E. (1959). Distribution of L-alanine and L-glutamate dehydrogenase in bacilli. Biochimica et biophysica acta 36, 288-289.

ITo, J. \& SptzizEN, J. (1971). Increased rate of asporogenous mutations following treatment of $B$. subtilis spores with ethyl methane-sulfonate. Mutation Research 13, 93-96.

Jaskunas, S. R., NomuRA, M. \& Davies, J. (1974). Genetics of bacterial ribosomes. In Ribosomes, pp. 333-368. Edited by M. Nomura, A. Tissieres, \& P. Lengyel. Cold Spring Harbor: Cold Spring Harbor Laboratory.

Kane, J. F. \& Deshpande, K. L. (1979). Properties of glutamate dehydrogenase from Bacillus subtilis. Biochemical and Biophysical Research Communications 88, 761-767.

KoHNO, T. \& RoTH, J. (1979). Electrolyte effects on the activity of mutant enzymes in vivo and in vitro. Biochemistry 18, 1386-1392.

MARMUR, J. (1961). A procedure for the isolation of deoxyribonucleic acid from microorganisms. Journal of Molecular Biology 3, 208-218.

Neuhard, J., PRICE, A. R., Schack, L. \& Thomassen, A. (1978). Two thymidylate synthetases in Bacillus subtilis. Proceedings of the National Academy of Sciences of the United States of America 75, 1194-1198.

O'Donovan, G. A. \& Ingraham, J. L. (1965). Cold-sensitive mutants of Escherichia coli resulting from increased feedback inhibition. Proceedings of the National Academy of Sciences of the United States of America 54, 451-457.

Reysset, G. \& Aubert, J. P. (1975). Relationship between sporulation and mutations impairing glutamine synthetase in Bacillus megaterium. Biochemical and Biophysical Research Communications 65, 1237-1241.

Schaeffer, P., Millet, J. \& Aubert, J.-P. (1965). Catabolic repression of bacterial sporulation. Proceedings of the National Academy of Sciences of the United States of America 54, 704-711.

SPIZIZEN, J. (1958). Transformation of biochemically deficient strains of Bacillus subtilis by deoxyribonucleate. Proceedings of the National Academy of Sciences of the United States of America 44, 1072-1078.

TyLER, B. (1978). Regulation of the assimilation of nitrogen compounds. Annual Review of Biochemistry 47, 1127-1162.

WilcoX, M. \& NiRENBERG, M. (1968). Transfer RNA as a cofactor coupling amino acid synthesis with that of a protein. Proceedings of the National Academy of Sciences of the United States of America 61, 229-236. 